\title{
1. Fundamental rights as a political myth of the EU: can the myth survive?
}

Stijn Smismans*

\section{INTRODUCTION}

Political authority, particularly in a democracy, requires justification. Legitimating narratives can be mere PR actions, part of sectoral policy paradigms, ${ }^{1}$ or part of the ideational repertoire of broader 'governance architectures', that is, strategic and long-term political initiatives of international organisations on cross-cutting policy issues. ${ }^{2}$ However, such (cross-)policy related arguments are unlikely to be sufficient. Nation states have traditionally crafted narratives that give a 'raison d'être' to the national polity, often related to issues of identity and memory. Such foundational narratives can be called 'political myths', that is, a narrative that is at least partially based on non-rational elements and contains factual error, but is widely appropriated as a shared belief of the foundational principles of a polity, referring to the past but spurring action in the political domain today. In this chapter I will argue that the European Union's (EU) approach and narrative on fundamental rights has the function of a political myth.

In the following section 2, I will first clarify the concept of political myth. Section 3 will then illustrate that fundamental rights were not part of the initial institutional design of the European Economic community (EEC)/EU as set out in the 1950s. Fundamental rights are thus not an ancestral political myth of the EU, in contrast to, for instance, the myth of 'peace through European integration'. Despite this absence in the initial institutional design, the EEC/EU has gradually developed fundamental rights narratives. Section 4 analyses the foundational nature of these narratives. While they developed (partially) at different moments in time, and in relation to different policy sectors, they are strongly interwoven and have a common basis of foundational claims, of which the repeated narration suggests we are dealing with a shared belief. Section 5 analyses how the myth has been successful. It is the irony of myths that, despite containing 'factual error', they are believed in and acted upon. While we can identify factual error and contradictions in the EU's fundamental rights myth, it has contributed both to legitimising the European polity and to stirring to action in the defence of fundamental rights. However, in the last section I will argue that, particularly in the

* I would like to thank Dr Rachel Minto for research assistance.

1 Peter Hall, 'Policy paradigms, social learning, and the State: the case of economic policymaking in Britain' [1993] 25 Comparative Politics 275.

2 Susana Borras and Claudio M. Radaelli, 'The politics of governance architectures: creation, change and effects of the EU Lisbon Strategy' (2011) 18(4) Journal of European Public Policy 463, 464. 


\section{Research handbook on EU law and human rights}

light of the economic crisis, the tension between reality and fiction in the EU's fundamental rights myth may have been stretched too far, to the extent that its role as a political myth that may provide legitimacy for the European polity and may stir action for the values it purports is at risk.

\section{ON THE ROLE OF POLITICAL MYTHS}

Many definitions of 'political myth' have been provided. ${ }^{3}$ I consider the following elements to be the core features of a political myth. Firstly, referring to early Greek philosophy 'mythos' is a narrative that includes non-rational elements, whereas 'logos' would refer to what we can observe and understand using rational thought. Ernst Cassirer more explicitly opposes the rational to emotion and feelings, and argues that 'myth does not arise solely from intellectual processes; it sprouts forth from deep human emotions' ${ }^{4}$ The easiest way then to talk about a myth is to point to factual error in the narrative, or to illustrate the difference between fiction and 'reality', the latter being constructed through the inherent logic of assumingly rational (scientific) disciplines. However, my aim here is not to talk about a political myth as soon as we find a rebuttable claim in political discourse. ${ }^{5}$ The important first element in a political myth is that it is a story one can be made to believe, although it can include 'factual error'. 'Myths have a loose relation to - or are detached from - reality. It does not matter if myths are true, partly true, or blatantly false. What matters is that perfectly reasonable people believe them to be true'. ${ }^{6}$ How much 'factual error' there is exactly in the narrative is not my main issue of concern, although I will point to such tensions between the story and 'reality' and analyse whether such contradictions finally undermine the myth. Rather I want to understand how such a narrative, which includes factual error, becomes part of political discourse in the European Union. To talk about a political myth several other features are required.

The second feature of a political myth is that it refers to the past but spurs to action in the present. 'It is typically a tale concerned with past events, giving them a special meaning and significance for the present.' 7 According to Sorel 'myths must be judged as a means of acting on the present', ${ }^{8}$ and as 'expressions of a will to act'. 'A myth

3 Ernst Cassirer, The Myth of the State (New Haven/London: Yale University Press 1946); Henry Tudor, Political Myth (London: Pall Mall Press 1972); Christopher G Flood, Political Myth (London: Routledge 2002).

4 Cassirer (n 3) 43.

5 Elsewhere Stijn Smismans, 'New modes of governance and the participatory myth' (2008) 31(5) West European Politics 874. I have used the concept of myth in such a way, namely to dimystify repeated claims by European institutional actors regarding the participatory features of new modes of governance.

6 Sam-Sang Jo, European Myths. Resolving the Crises in the European Community/ European Union (Lanham, MD: University Press of America 2007) 39.

7 Tudor (n 3) 16.

8 Georges Sorel, Reflections on Violence (Cambridge: Cambridge University Press 1999) 16.

9 ibid 19. 
becomes important when people believe it to be true and when they act on that belief.' ${ }^{10}$ This does not imply that every person telling the myth does so consciously to act on the present, but the narrative does have this potential. ${ }^{11}$ Barthes stresses the intentionality or motivation dimension in political myths; myths matter for what they do, not for what they say, and their meaning resides in the act of communication between the makers of the myth and their consumers. ${ }^{12}$ Berger and Luckmann, though, qualify the strength of motivation and the resulting consistency of political myths. ${ }^{13}$ They suggest that mythology should be distinguished from ideology and theology: myth-makers have a weaker motivation and a lower regard for consistency while ideologists are much more rigidly determined and religious proponents give harsh treatment to dissenters or heretics. ${ }^{14}$ Obviously, besides ideology there are many other political discourses which contain factual error and are expressions of acting on the present. To constitute a political myth two other features are essential; 'hegemonic role' and 'foundational character'. According to Lieberman and Gray, ${ }^{15}$ with reference to Laclau, ${ }^{16}$ 'successful myths, once created, whether true or false, and whatever their social meaning, assume a life and energy on their own, developing a political momentum that is hard, if not impossible, to force back into the bottle. This is political hegemony, and it lasts as long as the myth expresses what people believe ...' A discourse by a single set of political actors does not constitute a political myth. Political myths need to be widely shared, and a regular frame of reference. This means we have to look both at who are the story-tellers and how the myth is 'appropriated'. To play such a 'hegemonic role' myths will often refer to broad 'concrete universals'.

This leads us to the last defining aspect of a political myth, namely its subject matter. In a minimalist conceptualisation of political myth, one can include all sorts of narratives which are (partially) based on non-rational arguments and that obtain a rather hegemonic place within the belief system of a particular policy sector, thus influencing political process and policy-making. Lieberman and Gray, ${ }^{17}$ for instance, describe how the myths of Frankenstein foods and superweeds have influenced policies on genetically modified foods and crops. However, I use the concept of political myth here in its more maximalist interpretation as a narrative that relates to the assumingly foundational origins of a polity and generates legitimacy for political rule. Such political myths have mainly been developed in relation to the nation state and our question is whether the European Union has such foundational myths that refer to the nature of the polity, its legitimacy and questions of belonging. In such maximalist understanding, all political

10 Jo (n 6) 39.

11 Flood (n 3) 43.

12 Roland Barthes, Mythologies (translation A. Lavers, Paladin 1972) 126-7; as quoted by Erik Jones, 'The economic mythology of European integration' (2010) 48(1) Journal of Common Market Studies 89, 91.

13 Peter L Berger and Thomas Luckmann, The Social Construction of Reality: A Treatise in the Sociology of Knowledge (Harmondsworth: Penguin 1966) 122-43.

14 Jones (n 12) 93.

15 Sarah Lieberman and Tim Gray, 'The role of political myth in the international conflict over genetically modified foods and crops' (2007) 17 European Environment 376, 379.

16 Ernesto Laclau, New Reflections on the Revolution of Our Time (London: Verso 1990).

17 Lieberman and Gray (n 15) 376. 
myths are by definition 'foundational' as they relate to the foundational principles of the polity, but as this chapter will show one can distinguish between ancestral political myths, which have been permanently present since the creation of the European polity, and complementary political myths, which make equally foundational claims, but do so by linking in to the ancestral myths at a later moment in time.

We can thus define a political myth as a narrative that is at least partially based on non-rational elements and contains factual error, but is rather hegemonic as a shared belief of foundational principles of a polity, which refers to the past but spurs action in the political domain today.

It results from this definition that political myths are neither intrinsically good nor bad. The mere fact that the myth contains factual error does not make it a bad thing. Political myths can have two main functions; they provide legitimacy for the polity and/or inspire action in function of the values inherent in the myth. Whether that is morally desirable or not depends on the nature of the regime and the values supported by the myth. One can argue that if a myth is used to sustain an authoritarian regime it is not desirable, if it supports legitimacy and social cohesion in a democratic regime it is. At the same time, if the myth inspires action in the function of, for instance, identity politics that lead to exclusion it can be argued it is not morally desirable, while the opposite can be said from a myth stirring action in the defence of fundamental rights. This chapter neither aims at discussing the moral value of fundamental rights nor of the European polity. Its objective is not normative but analytical. It analyses how the EU has used fundamental rights as a political myth and assesses to what extent that myth has been successful in providing legitimacy to the European polity and supporting the values of fundamental rights underlying the myth.

\section{A FOUNDATIONAL MYTH, BUT NOT REALLY AN ANCESTRAL MYTH}

The narrative of European integration based on a desire for European unity after the dramatic experiences of World War I and World War II is surely the most commonly appropriated and well documented European myth. ${ }^{18}$ It also functions as a sort of ancestral myth on which other European myths are anchored. This is, for instance, the case with the myth of fundamental rights. Following World War II many political actors and organisations were pleading for European integration, with the European Movement favouring a federalist design in which respect for fundamental rights was an important cornerstone. ${ }^{19}$ This political movement led in 1949 to the creation of the Council of Europe which, ${ }^{20}$ according to its Statute, has the aim to achieve greater unity between its members by common action in 'economic, social, cultural, scientific, legal and administrative matters and in the maintenance and further realisation of

\footnotetext{
18 Jo (n 6) 47-53.

19 Ralph Beddard, Human Rights and Europe, 3rd edn (Cambridge: Cambridge University Press 1995) 19.

20 Derek W. Urwin, 'The European Community: From 1945 to 1985 ' in Michelle Cini (ed.), European Union Politics, 2nd edn (Oxford: Oxford University Press 2007) 17.
} 
human rights and fundamental freedoms'. The latter arose immediately on the agenda of the new organisation, leading to the adoption in 1950 of the European Convention on Human Rights, perceived by many delegates to the Council 'almost as a constitutive document of a European federation, a sort of Magna Carta of European political union'. ${ }^{21}$

However, beyond the general idea of European cooperation and unity to ensure peace, the multitude of political actors was divided on the strategy to follow and on what such unity would actually mean. This was illustrated in the weak institutional design of the Council of Europe, but even more so in the failed creation of a European Political Community in 1954. The six member states of the European Coal and Steel Community (ECSC) aimed at a deeper political union in which fundamental rights had a central place. Not only would the new Community have to respect fundamental rights, the role of the new supranational court in this was discussed, and the Community would play a role in ensuring respect of fundamental rights in its member states, ${ }^{22}$ an approach which made particular sense given the recent experience. However, the negotiations on the European Political Community fell apart due to the failure to adopt the parallel European Defence Community. As a result, a more modest and sectoral road to European integration was taken. While the European Movement was favouring a political community on a federalist design, much akin to Altiero Spinelli's 1940 and 1941 manifesto for a 'free and united Europe', others argued that European unity could best be achieved by economic cooperation on a sectoral level. Jean Monnet stood aloof from the European movement, which he considered too populist, and from the Council of Europe that emerged from it. ${ }^{23}$ As well illustrated, ${ }^{24}$ his functionalist and more technocratic approach has characterised the ECSC, the European Economic Community (EEC) and Euratom. Although De Búrca shows that none of the founding member states of the ECSC and the EEC had a problem with the idea of a supranational community playing a prominent role in fundamental rights while they were negotiating on the European Political Community, ${ }^{25}$ the fact remains that the route taken in the EEC Treaty is clearly different.

The original EEC Treaty did not include any reference to fundamental rights. Like the Council of Europe, the European Communities were based on the ancestral myth that European integration was needed to ensure peace and avoid repetition of the terrible experiences of the two world wars. Yet, while the Council of Europe placed fundamental rights centre-stage, for the EEC, integration was economic and functional, without a constitutionalising process including fundamental rights. Contrary to the requirements for membership in the Council of Europe, respect for fundamental rights was not explicitly set as a condition to join the EEC. This omission was not accidental

\footnotetext{
21 Beddard (n 19) 43.

22 Gráinne De Búrca, 'The road not taken: the European Union as a global human rights actor' [2011] AJIL 649, 654-64.

23 Desmond Dinan, Ever Closer Union (Palgrave 2005) 15.

24 Kevin Featherstone, 'Jean Monnet and the "democratic deficit" in the European Union' (1994) 32 Journal of Common Market Studies 149.
}

25 De Búrca (n 22) 663. 
but the result of a deliberate choice. ${ }^{26}$ The functional economic approach, independent from fundamental rights, found support with many political actors at the time. That fundamental rights were not inherent in the EEC's set-up is, for instance, wellillustrated in the initial reactions to the intentions of Spain under Franco to join the EEC: initially, none of the six EEC countries' foreign ministers raised the possibility that fundamental rights would need to be respected, and in particular both the German and French governments appeared ready to accept fascist Spain as a member. ${ }^{27}$ That fundamental rights were not the domain of the EEC was also expressed in the initial case law of the European Court of Justice (CJEU) which resisted attempts by litigants to invoke fundamental rights and was unwilling to treat them as part of the Community legal order, considering that it was not Community competence to deal with infringements of national constitutional principles. ${ }^{28}$

Hence, the narrative of a Europe of fundamental rights is not a real ancestral myth of the EEC/EU. Although fundamental rights were discussed before the creation of the EEC, the route taken in the latter clearly did not provide a place for it. Yet this has not impeded the EEC/EU from developing narratives on fundamental rights at a later stage, which claim retrospectively that fundamental rights are and have always been inherent in the EEC/EU. As we will see shortly, these narratives have a foundational character and act as a complementary myth anchored in the initial ancestral myth of European integration ensuring peace.

\section{NARRATIVES ON FUNDAMENTAL RIGHTS AND THEIR FOUNDATIONAL CHARACTER}

One can identify four main narratives that have developed over time and are partially interwoven: the legal, constitutionalising, social rights and external relations narratives. All show elements of mythical narration, making foundational claims on the nature of the European polity, its legitimacy and questions of belonging. This foundational rhetoric has two dimensions. First, it claims that fundamental rights stood at the cradle of the EEC/EU, which is often linked to the ancestral myth of "peace through European integration'. Second, it often makes more profound claims about fundamental rights being inherent to the European project because there would be a common tradition in Europe of particularly strong fundamental rights protection.

26 Manfred Dauses, 'The protection of fundamental rights in the Community legal order' (1985) 10 EL Rev 398, 399; Daniel C. Thomas, 'Constitutionalization through enlargement: the contested origins of the EU's democratic identity' (2006) 13(8) Journal of European Public Policy 1190.

27 Thomas (n 26) 1196.

28 Case 1/58 Stork v High Authority [1959] ECR 17; Case 40/64 Marcello Sgarlata and others $v$ Commission of the EEC [1965] ECR 215. 


\subsection{The Legal Narrative: Fundamental Rights as Principles of Community Law}

While the CJEU had initially excluded fundamental rights from the legal order of the EEC, it changed its position in a series of cases at the beginning of the 1970s. In Stauder $^{29}$ in 1969 the CJEU stated that fundamental rights are 'enshrined in the general principles of Community law and protected by the Court'. In the absence of any Treaty change, what led to this Copernican revolution in the CJEU's case law? The first intensive debate that developed on the relation between the EEC and fundamental rights was one in which European law was seen as a threat and not as a guarantee for the respect of fundamental rights. Several national constitutional courts argued that there was indeed no guarantee that the Community institutions and Community law would respect fundamental rights. The German Constitutional Court, for instance, argued in Solange (1974), ${ }^{30}$ that in the absence of a European bill of rights and a directly elected European Parliament, it could not be taken for granted that Community law respected fundamental rights. Several constitutional courts conditioned the supremacy of European Community (EC) law by arguing they would check whether EC law infringed the fundamental rights enshrined in their national constitution. Finding itself in a defensive position, the CJEU argued that Community law did respect fundamental rights, and that - in the absence of a bill of rights - it would ensure this by applying general principles of Community law, based on common national traditions and on international texts agreed to by the member states.

Williams has persuasively analysed the mythical narration in this case law. ${ }^{31}$ When the Court stated in Stauder that fundamental rights 'were enshrined in the general principles of Community law and protected by the Court' no in-depth consideration of this crucial claim was provided and fundamental rights were boldly embraced as an-already-present constitutional given. ${ }^{32}$

The Court did not provide a specific definition of the fundamental rights that would be guaranteed by the Treaty or in the general principles of Community law. The Court's narrative tended to be mythical rather than strictly legally argued. With the general reference to 'principles' the Court confirmed the symbolic attachment to 'human rights' and installed a legally authenticated history of the Community's ethical origins and design. ${ }^{33}$ But on what is the protection of fundamental rights as 'principles of Community law' based? The clarification provided by the CJEU further strengthens the mythical narrative rather than providing detailed legal argumentation and definition. In Internationale Handelsgesellschaft the Court argued that inspiration for the general principles is found in the 'constitutional traditions of the Member States', evoking the idea of a common European tradition in the respect of human rights, a tradition that is inherent in the Community legal order. While this idea of general principles based on

\footnotetext{
29 Case 29/69 Erich Stauder v City of Ulm - Sozialamt [1969] ECR 419.

30 Internationale Handelsgesellschaft GmbH $v$ Einfuhr- und Vorratsstelle fur Getreide und Futtermittel (No 2, BVL 52/71 Bundesverfassungsgericht) [1974] 2 CMLR 540, 549-50.

31 Andrew Williams, EU Human Rights Policies. A Study in Irony (Oxford: Oxford University Press 2004) 140-57.

32 ibid 147.

33 ibid 148-9.
} 
the common traditions of the member states has become standard rhetoric in the Court's case law dealing with fundamental rights, in practice it has hardly ever tried to substantiate such rights from a comparative analysis of national constitutions. ${ }^{34}$ Its use is clearly more symbolic and mythical rather than legally practical as such a comparative exercise may not only be difficult but also disappointing. The Court, therefore, prefers to rely on the second source of inspiration for the general principles of Community law, as indicated in Nold, ${ }^{35}$ namely international treaties 'on which the Member States have collaborated or of which they are signatories'. More particularly, the CJEU refers mainly to the ECHR, which is said to have a 'special significance' as a key source of inspiration for the general principles of EC law. ${ }^{36}$ By referring nearly exclusively to the ECHR, and not to, for instance, the Universal Declaration of Human Rights, the CJEU contributes to the mythical construction that human rights protection is something particularly 'European'.

\subsection{The Constitutionalising Narrative}

Although the CJEU's case law on fundamental rights is commonly described as an illustration of the constitutionalisation of the European legal order, 'constitutionalising narrative' in this chapter refers to the explicit inclusion of fundamental rights as foundational principles in the constitutional texts of the EU, and the strategic use of constitutional references by the political institutions to increase support for European polity-building. While the legal debate on fundamental rights developed as a dialogue between constitutional courts and the CJEU, the European political institutions hardly referred to fundamental rights until at least the end of the 1970s. In 1977 the European Parliament, the Council and the Commission adopted a Joint Declaration on Fundamental Rights, stressing 'the prime importance they attached to the protection of fundamental rights', derived from the constitutions of the member states and the ECHR. The Declaration can be read as a political confirmation of the case law and a defensive statement that EC law does respect fundamental rights rather than a strong commitment for a pro-active role as guardian of such rights. The Single European Act appeared to go a step further by stating that the Community was 'determined to work together to promote democracy on the basis of fundamental rights' (emphasis added) but this reference was only made in the Preamble without providing any substantial Treaty change. It is only in the Maastricht Treaty (later Article 6(1) of the Treaty on European Union (TEU)) that fundamental rights were set out in the Treaty itself as foundational principles of the European Union. The corresponding provision (Article 2 TEU) following the Lisbon Treaty states: 'the Union is founded on the values of respect for human dignity, freedom, democracy, equality, the rule of law and respect for human rights, including the rights of persons belonging to minorities'. By stating that the Union is founded on these principles, the impression is given that they have always

34 Paul Craig and Gráinne De Búrca, EU Law, 4th edn (Oxford: Oxford University Press 2008) 386.

35 Case 4/73 J. Nold, Kohlen- und Baustoffgroßhandlung $v$ Commission of the European Communities [1974] ECR 491, 507.

36 Craig and De Búrca (n 34) 384. 
been at the origin of the European Communities. This is strengthened by the Preamble of the EU Treaty which first recalls 'the historic importance of the ending of the division of the European continent and the need to create firm bases for the construction of the future of Europe', and subsequently confirms its 'attachment to the principles of liberty, democracy and respect for human rights and fundamental freedoms and of the rule of law'. Respect of fundamental rights is thus directly linked to the ancestral myth of 'peace through European integration'. The mythical construction is further strengthened by stating that these principles are "common to the Member States' (Article 2 TEU), hence evoking the common European heritage on which the protection of fundamental rights is built. This narrative was further strengthened by a new statement in the Preamble of the TEU, inserted by the Lisbon Treaty, that the signatories to the Treaty are 'drawing inspiration from the cultural, religious and humanist inheritance of Europe, from which have developed the universal values of the inviolable and inalienable rights of the human person, freedom, democracy, equality and the rule of law'.

The 'European' foundation of the fundamental rights protection is equally confirmed in Article 6 TEU which indicates as (only) sources of inspiration for the general principles of community law, the common traditions of the member states and the ECHR. Non-European texts such as the Universal Declaration of Human Rights are not referred to.

While the Maastricht Treaty had provided the EU neither with powers in relation to respect of fundamental rights in the Member States, nor with the legal capacity to develop a real coherent human rights policy, the Amsterdam Treaty went a step further by making respect of fundamental rights a condition for membership of the European Union (Article 49 TEU). Moreover, since Amsterdam, Article 7 TEU empowers the Council to suspend some of the voting and other rights of a member state when it is found to be responsible for a serious breach of the fundamental principles in Article 2. The EU's foundational principle of fundamental rights is thus clearly no longer simply a question of whether the Community institutions respect fundamental rights but extends to the constituting members of the European polity. The EU can present itself as a beacon of fundamental rights protection because both its institutions and the member states respect these rights, and the EU plays a guardian role in relation to the latter.

The constitutionalising narrative on fundamental rights came to a head with the debate on the Charter of Fundamental Rights of the EU. The main objective of the Charter was to create polity-support by bringing the EU closer to the citizen through a bill of rights, facilitated by a relatively public and participatory drafting process through the Convention. The Convention debate illustrates the different expectations in relation to an EU fundamental rights narrative. The minimalist option, represented mainly by the UK, prioritises the ECHR and would rather not have a separate EU text, and if there has to be one, this should not in any way be a constitutionalising text but only aim at restraining Community competence and ensuring the EU institutions respect fundamental rights. Yet, for most member states the Convention had to be a constitutionalising process, at least in the sense of a legitimising and polity-building process around a consolidating text of rights. Moreover, many Convention participants, in particular the representatives of the European Parliament and a large majority of the 
national parliament representatives, saw the Convention more profoundly as setting out the foundational rights and principles of the European polity as guidance for further European integration. ${ }^{37}$

The Charter, as adopted in Nice in 2000, reflects these tensions. The minimalist position led to the well-known limitations of the text; namely initially its non-binding nature, and still now; not creating new EU competences and applying only to the EU institutions and the member states when implementing EU law. However, the Charter is also innovative in bringing together in one document civil, political and social rights and including innovative provisions such as prohibition on reproductive human cloning. Its Preamble strengthens the mythical narration, referring to 'an ever closer union ... to share a peaceful future based on common values ... conscious of its spiritual and moral heritage'. The Union is said to 'contribute ... to the preservation and to the development of these common values ... . To this end, it is necessary to strengthen the protection of fundamental rights in light of changes in society, social progress and scientific and technological developments by making those rights more visible in a Charter'. The sources of inspiration are again the European texts on fundamental and social rights adopted by the EC and Council of Europe $(\mathrm{CoE})$. While it is said that the Charter 'reaffirms' these rights the statement that the EU 'contributes to the development of the common values' and intends to strengthen protection in light of societal change, suggests the EU has also a proactive role in the protection and promotion of fundamental rights. The Lisbon Treaty completes the constitutionalisation process and European anchoring of fundamental rights by making the Charter binding (Article 6(1) TEU) and promising accession of the EU to the ECHR (Article 6(2) TEU).

\subsection{The Fundamental Social Rights Narrative}

Academic accounts of the evolution of fundamental rights in the EU often jump from the legal debate of the 1970s to the constitutionalising events of the 1990s. However, it was during the second part of the 1980s that the fundamental rights narrative appeared strongly for the first time in the European political debate. This fundamental rights narrative developed in the context of a debate on Europe's social dimension, and is therefore often only dealt with marginally by human rights scholars. However, it also had an important influence in inciting and framing the constitutionalising narrative of the 1990s as described above. It is not by accident that the main institutional anchoring for fundamental rights during all these years was the Commission's Directorate General for Social Affairs. The debate had been launched by Commission President Delors, for whom the leap forward in building the single market had to be accompanied by progress in Europe's social dimension. After having invited the European Economic and Social Committee (EESC) to adopt an opinion to give 'a clear message on the

37 Win Griffiths, 'A Charter of Fundamental Rights of the European Union: a personal political perspective' in Federal Trust for Education and Research, The EU Charter of Fundamental Rights (Federal Trust series, Constitution for Europe, Federal Trust 2000) 47. 
future of the Community and the fundamental values it intends to promote', ${ }^{38}$ the Commission pressed ahead with the idea of a Community Social Charter aiming to constitutionalise social citizenship guaranteeing a wider range of rights than the CoE's European Social Charter of 1961, which had been referred to in the Preamble of the Single European Act. ${ }^{39}$ The idea of fundamental social rights in the Community context was a strongly disputed one. When the Community Social Charter was adopted in 1989 its scope had been reduced from social rights for all citizens to rights for workers, it had no binding force and the UK had opted out. Yet, the debate which linked fundamental rights with the social dimension set a trend for the fundamental rights discourse for years to come. It was DG Social Affairs that twice commissioned a committee of experts - the 1996 Comité des sages and the 1999 Simitis Committee - to look into the status of fundamental social rights and the option to adopt a Bill of Rights. While the initial task of the 1996 Committee focused on the status of social rights, its final plea in favour of the indivisibility of civil, political and social rights and inclusion of such rights in the Treaties or in a Bill of Rights, broadened the debate to a general discussion on the place of such a Bill of Rights in the European construction. The 1999 Committee was asked from the start to address the possibility of such a broader Charter, a suggestion finally leading to the Charter. We thus see a common thread in the fundamental rights narrative from the late 1980s to the late 1990s - with DG Social Affairs as the main institutional anchor point - from a focus on social rights as a complement to the single market to a more constitutionalising discourse. On the one hand, we see a set of actors for whom the constitutionalisation of social rights in the Charter was the logical consequence of a debate on the European social dimension started much earlier. On the other hand, those who would have preferred a Charter to be only a consolidation of 'traditional' fundamental rights to 'bring the citizen closer to the EU', had allowed an opening to a Pandora's Box, as any debate on the foundational values of the EU was bound to be also a discussion on the place of social rights in the EU's predominant economic constitution.

In this meeting of the social rights and constitutionalising narratives, the mythical narration is strengthened by increased foundational claims in relation to social rights, both by suggesting that such rights are inherent to the European construction, and by relating this to a common European heritage on the social dimension. The debate preparing the Community Social Charter was clearly one of the common social values that would also inspire the European integration process, ${ }^{40}$ although the Preamble of the final document refrained from including a specific reference to a common European heritage. During the 1990s, social rights became more explicitly part of constitutionalising references indicating the foundations of the European polity. In the Preamble of the EU Treaty, the ancestral myth of peace, the reference to fundamental rights and to social rights are placed in a logical sequence. The EU is not only 'attached to' human

38 Marinella Neri Gualdesi, 'Esiste un modello sociale europeo? Il contributo del CES all'elaborazione della Carta comunitaria dei diritti sociali fondamentali del 1989' in Antonio Varsori (ed.), Il Comitato Economico e Sociale nella costruzione europea (Venice: Marsilio 2000) 197.

39 Jeff Kenner, EU Employment Law (Oxford: Hart Publishing 2003) 116.

40 Gualdesi (n 38). 


\section{Research handbook on EU law and human rights}

rights and fundamental freedoms but also to fundamental social rights as defined in the European Social Charter and the Community Social Charter. The reference is again to two 'European' texts, and not to, for instance, the standards of the International Labour Organisation (ILO), ${ }^{41}$ suggesting the European heritage of particularly strong protection of these norms. The debate around the 1990s expert committees reinforces references to the common European social heritage as a basis for the fundamental social rights of the EU. The report of the 1996 expert committee starts with the claim: 'Civic and social rights originated in Europe ... This is our heritage and forms the basis of our concept of citizenship.' When the Charter finally includes social rights amongst the fundamental rights of the Union, particularly in its Title IV on Solidarity, this is done with reference in its Preamble to the common values on which the EU is founded, namely human dignity, freedom, equality and solidarity.

\subsection{The External Relations Narrative}

Fundamental rights have taken a central position in the EU's external relations. Although occasional references and implicit considerations on fundamental rights appeared from the 1970s onwards in the EU's development policy and talks with potential candidate countries, ${ }^{42}$ the explicit political narrative on fundamental rights in external relations really developed during the 1990s. This was obviously stirred by the creation of a real Common Foreign and Security Policy (CFSP) in the Maastricht Treaty, and the fall of the Iron Curtain which opened the prospect of enlargement to a high number of new countries with a contestable human rights record. In March 1991, the Commission set out for the first time its policy on development, democracy, and human rights in external relations, ${ }^{43}$ followed in November 1991 by a Joint Resolution of the Council and the member states giving high priority to stimulating respect for human rights. The Maastricht Treaty mentions an explicit objective of the CFSP, 'to develop and consolidate democracy and the rule of law, and respect for human rights and fundamental freedoms' (now Article 21 TEU). In the context of enlargement, the Amsterdam Treaty makes the respect of fundamental rights explicitly a condition for membership of the European Union (now Article 49 TEU). Amongst the conditionality requirements for membership, fundamental rights are thoroughly scrutinised through the process of association and accession agreements with candidate countries.

These developments on the external dimension are strongly interwoven with the polity-building and constitutionalising dynamics of the 1990s. When the Maastricht Treaty sets fundamental rights as a condition for membership this is both an internal identification of the European polity, but also a positioning of the EU vis-à-vis the outside world. It presents the EU as the lighthouse of fundamental rights in the dark world of less civilised regimes. Fundamental rights become increasingly a central narrative and driving force in the EU's foreign policy, to an extent the EU has been

\footnotetext{
41 The Community Social Charter itself did refer to the ILO.

42 Williams (n 31) 40-4, and 54-8.

43 Commission 'Communication of 25 March 1991 on Human Rights Democracy and Development Co-operation' SEC (91) 61 final.
} 
described as a 'normative power' ${ }^{44}$ The EU presents itself both as 'the place of fundamental rights' and as the geographical power which, more than anyone else (and in particular the United States), bases its foreign policy on the high ideals of fundamental rights. As the Maastricht Treaty had set out in its Preamble, by implementing a CFSP the EU would reinforce the European identity. The addressees of this foundational narrative are not only external actors, but are at least as much the European citizens, in an attempt to build polity-legitimacy for the EU.

\section{THE SUCCESS AND THE IRONY OF THE MYTH: FACTUAL ERROR, BUT BELIEVED IN, TO ACT UPON}

The maximalist myth, as it results from the four main narratives identified above, is based on the idea that fundamental rights have always been at the origin of the EC/EU as a reaction to the war experience and given the particular strong common European heritage of fundamental rights protection. It implies not simply that Community institutions and EC law respect fundamental rights, but also that the EU acts as a guardian of fundamental rights in its member states and candidate countries, and provides higher fundamental rights standards than other international fora. Moreover, this superior European heritage makes the EU the ideal actor to promote fundamental rights throughout the world. The narrative is told in different settings and does not always imply all the maximalist claims, but there is a common ground of foundational claims which place fundamental rights as inherent to the EC/EU and based on a common heritage. Myths are internalised, not by a conscious learning process but through cumulative exposure. ${ }^{45}$ The narrative 'Europe-fundamental rights' can be so vague it allows for repeated referencing in Europe's multi-level polity, ensuring 'cumulative mythopoeic effects' 46 leading to broader myth appropriation. By referring to 'common traditions' the EU builds its fundamental rights credentials (also) on the fundamental rights protection provided by the member states. Moreover, it appropriates the ECHR nearly as its own, thus free-riding on the fundamental rights reputation of the CoE. In this way, the EU also avoids overly strong myth-competition with the member states or other international fora (the $\mathrm{CoE}$ in particular). Repeated references by the EU, the member states, and the CoE lead to myth-sharing in the common idea of fundamental rights as inherent in Europe. The myth of a Europe of fundamental rights thus often functions as a meta-story, linking Europe and fundamental rights, without having to be precise on format and institutions.

However, when one gets into the detail of the EU's narratives and fundamental rights practice, it is not difficult to find plenty of 'factual errors', contradictions and irony in the EU's fundamental rights approach. As illustrated above, fundamental rights were not in the initial design of the Rome Treaty. Tracing the EU's superiority on

\footnotetext{
44 Ian Manners, 'Normative power Europe: A contradiction in terms?' (2002) 40(2) Journal of Common Market Studies 235.

45 W. Lance Bennett, 'Myth, ritual, and political control' (1980) 30 Journal of Communication 166.

46 Flood (n 3) 64.
} 
fundamental rights further back to the common European heritage easily runs into problems too. Historical accounts of Europe's particular fundamental rights tradition as, for instance, expressed in the Enlightenment gloss over all the wars and bloodshed on the European continent and how they were exported beyond its borders. One can also question whether the claimed common values are really shared, in particular in relation to social rights, as illustrated in the opt-outs of both the CoE' Revised Social Charter of 1996 and the Community Social Charter, and the limits of the Charter.

Moreover, the origins of the EC as a process of market integration implies that the $\mathrm{EC} / \mathrm{EU}$ has often been seen as a threat rather than a guardian of fundamental rights. This is illustrated by the resistance of the constitutional courts, but also in the argument that the ECHR offers a better guarantee for fundamental rights protection than a proper EU system can offer. This reflects the concern that the CJEU has to interpret fundamental rights in the light of the EC/EU Treaties in which economic values are predominant. Ironically, the CJEU has described the four single market freedoms on a number of occasions as 'fundamental'. ${ }^{47}$ These 'fundamental' freedoms are justiciable and have direct effect, whereas the Court has eschewed the language of direct effect for human/fundamental rights provisions as principles of Community law or as set out in the Charter. ${ }^{48}$ Moreover, amongst the fundamental rights, social rights have a particularly weak position. Despite the rhetoric on 'indivisibility', there remain strong limits on the justiciability of fundamental social rights, amongst others due to the non-binding nature of the Community Social Charter and the confusing rights/principles distinction in the Charter.

Moreover, beyond the claim that the EU is founded on fundamental rights (Article 2 TEU), it has hardly been given any explicit competence in the field of fundamental rights. Except for the anti-discrimination provision of Articles 18-19 of the Treaty on the functioning of the European Union (TFEU), and the objective to promote fundamental rights in external policy (Article 21 TEU), the EU has hardly any legal basis to develop a real fundamental rights policy. Particularly, its powers as guardian of fundamental rights protection in its member states are weak. Member states have traditionally been resistant towards such supranational control, as again shown in the Charter being applicable to member states only when implementing EU law. The sanctioning mechanism of Article 7 TEU appears to hardly function in practice. It has only been used once, against an Austrian government that included the far right Austrian Freedom Party, and even then the EU leaders proved unable to defend a durable and coherent position on the issue. ${ }^{49}$ As a consequence, the EU has been repeatedly criticised on the grounds that its human rights standards and scrutiny in external policy and in conditions for accession are considerably more severe than the control it exerts in relation to its own member states.

47 Case C-49/89 Corsica Ferries France v Direction générale des douanes françaises [1989] ECR 4441; Case C-34/98 Commission of the European Communities v French Republic [2000] ECR I-1995.

48 Chris Hilson, 'What's in a right? The relationship between Community, fundamental and citizenship rights in EU law' (2004) 29 EL Rev 636, 640.

49 Cécile Leconte, 'The fragility of the EU as a 'community of values': Lessons from the Haider affair' (2005) 28(3) West European Politics 620. 
Hence it is not difficult to find contradictions in the EU's fundamental rights approach. However, the EU fundamental rights discourses have stirred action and have indeed had a transformative effect. By taking up fundamental rights as general principles of Community law, the CJEU has indeed started to assess Community action on fundamental rights grounds. Both the Commission and the European Parliament have also developed a practice in which all legislative proposals are assessed on grounds of fundamental rights. ${ }^{50}$ Moreover, not only do the Community institutions guarantee that Community law respects fundamental rights, the language of fundamental rights has also been a source of inspiration for European legislation in certain fields, as illustrated by the proactive use of the Community Social Charter for social policy legislation. The EU seeks to promote fundamental rights, not only on the basis of its explicit mandate for such promotion in the context of external relations, but also by using all available soft instruments it can proactively rely on. The '2007-2013 Fundamental rights and citizenship' programme (2007/252/EC), for instance, set the objective to 'promote the development of a European society based on the respect for fundamental rights', by Commission studies and research, and in particular by financial support to NGOs in the field.

The EU's efforts do not remain without effect. There is enough evidence to argue that in the context of enlargement the EU has had more political leverage than the CoE or the Organisation for Security and Co-operation in Europe in bringing applicant countries to comply with human rights standards. ${ }^{51}$ Despite its ad hoc approach and incoherence in ensuring the ethical dimension in its foreign policy, the Union has also contributed to global and regional issues in a manner that the individual member states simply cannot. ${ }^{52}$ Hence, while the maximalist version of the myth surely has its flaws, it is also clearly a narrative that has been acted upon and led to change.

\section{THE POLITICAL MYTH IN CRISIS}

While the fundamental rights myth has spurred action by institutional actors, the success of a political myth finally depends on wider myth appropriation within civil society. To a certain extent one can argue that the narrative of fundamental rights in the EU has developed from within civil society. The European integration process sprung from the multiple associations that in the post-war period argued for European unity, which led to the creation of the Council of Europe in which fundamental rights were

50 Olivier De Schutter, 'The EU Fundamental Rights Agency: genesis and potential' in Kevin Boyle (ed.), New Institutions of Human Rights Protection (Oxford: Oxford University Press 2009). However, on the limits of integrated impact assessments as a tool to ensure the mainstreaming of fundamental rights, see Stijn Smismans and Rachel Minto (2016), "Are Integrated Impact Assessments the Way Forward for Mainstreaming in the European Union?' Regulation and Governance. Advance online publication: doi:10.1111/rego.12119.

51 Bruno De Witte and Gabriel N. Toggenburg, 'Human rights and membership of the European Union' in Steve Peers and Angela Ward (eds), The European Charter of Fundamental Rights (Oxford: Hart Publishing 2004) 66.

52 Urfan Khaliq, Ethical Dimensions of the Foreign Policy of the European Union: A Legal Appraisal (Cambridge: Cambridge University Press 2008) 454. 


\section{8}

centre-stage. ${ }^{53}$ While this movement split up around the debate over the creation of the EEC, which took a functional instead of constitutionalising approach, civil society organisations stressing fundamental rights did not give up entirely on the EEC. For example, when fascist Spain applied to become a member of the EEC, a strong mobilisation of federalist militants, trade unions and European parliamentarians was able to change the attitude of the national governments, who were favouring accession, and thus ultimately blocked Spain's entrance. 54 This shows how the political myth of a Europe of fundamental rights is not just an institutional construct, but a narrative that existed in civil society, even despite the lack of a constitutional basis in the EEC Treaty, and against the dominant belief of core political actors at that time. As the EC/EU gradually engaged in a fundamental rights discourse, more frequent interactions developed between myth-makers in and outside the institutions, particularly around the Convention drafting the Charter and subsequently the Convention on the Constitutional Treaty. However, the involvement of certain elite actors in myth-making and mythmimicking is far from a guarantee that the myth is widely appropriated in civil society, and even less that it would provide polity-support. Suffice it to remember that the inclusion of the Charter in the Constitutional Treaty did not convince the French or Dutch to vote in favour of the latter.

In fact, despite the increased constitutionalisation of fundamental rights in the EU over the last decade, several developments in that same period increasingly undermined the potential role of the fundamental rights myth, to the extent that one can question its survival. This is due to the increased tension between reality and fiction in the myth, as well as to the more existential crisis the EU is going through following the economic crisis. As mentioned above, factual error is inherent to political myths. However, the more reality contradicts the myth, the less likely people will appropriate the myth and act upon it. From this perspective political myths are more vulnerable than ideology or religion as they lack the consistency and rigidity with which the defenders of ideology and religion will narrate their truth, and their lifespan is therefore more likely to be similar to Thomas Khun's scientific paradigms than to that of ideologies or religions. ${ }^{55}$

Over the last decade, several elements have stretched the tension between fiction and reality to the limit.

First, over the last decade the EU has expanded its action particularly in areas where civil and political rights are most at risk of breach, such as anti-terrorism measures, immigration, police and judicial cooperation, and criminal justice. Human rights associations and activists have strongly criticised 'Fortress Europe'. In terms of fundamental rights narratives, the EU's approach during the first decade of the 21st century has also been confusing. In addition to the four narratives identified above, the focus shifted to 'a European area of freedom, security and justice', in which

53 Alan Hick, 'Il tema della politica economica e sociale nel dibattito dei movimenti europeisti' in Antonio Varsori (ed.), Il Comitato Economico e Sociale nella costruzione europea (Venice: Marsilio 2000) 27.

54 Daniel C. Thomas, 'Constitutionalization through enlargement: the contested origins of the EU's democratic identity' (2006) 13(8) Journal of European Public Policy 1190.

55 Peter Berger and Thomas Luckmann, The Social Construction of Reality: A Treatise in the Sociology of Knowledge, (Harmondsworth: Penguin 1966) 122-43, as quoted by Erik Jones (n 12) 93. 
fundamental rights were institutionally mixed up with (and potentially subordinated to) the areas of policy intervention where a breach is most likely. The main responsibility for fundamental rights within the Commission moved from the DG for Employment and Social Affairs, where it had been used to build up support for increased social rights protection, to the DG for Justice and Home Affairs, where it got mixed up with the objective of 'security' which is potentially in contradiction with fundamental rights. ${ }^{56}$ Due to the critique from civil society and member states, the second Barroso Commission created two separate DGs, namely DG Justice (including responsibility for fundamental rights) and DG Home Affairs, reflected in separate Commission portfolios. This has alleviated the institutional tension, and strengthened the EU's fundamental rights record in areas of justice and home affairs (compared to the previous 'securitisation' stage post 9/11), although the overall approach to migration and asylum remains under critique, as well as its consequences and abuses in the countries at the (closed) gate of Fortress Europe. ${ }^{57}$

Second, while the EU has entered new areas where it may affect civil rights, its core remains a market building project. Its key tension in relation to fundamental rights therefore lies in its effect on social rights. While the EU's freedoms of movement have been defined as fundamental rights, the EU's social rights discourse and protection remains particularly weak. Despite the inclusion of social rights in the Charter (as principles rather than rights) the last decade has seen an increased predominance of economic over social rights. This is, for instance, witnessed in the case law of the Court (in cases such as Laval, Viking and Rüffert), but also in the move to the open method of coordination (OMC) as a way to deal with social issues through soft benchmarking, rather than through a rights approach. Although the OMC and rights protection are not antithetical, and OMC type procedures could in theory be used to assess systematically the attainment of fundamental (social) rights, ${ }^{58}$ such a link has not been developed in practice.

The EU's social policy move to benchmarks and statistics rather than rights has happened parallel to the institutional relocation of fundamental rights from (DG) Social Affairs to (DG) Justice (and Home Affairs), thus further increasing the gap, both conceptually and in terms of resources, between social policy and fundamental rights. This increasing gap is particularly problematic in the light of the economic crisis which

56 On the tension between 'freedom' and 'security' in this approach, see Didier Bigo, Sergio Carrera and Elspeth Guild 'The CHALLENGE Project: final policy recommendations on the changing landscape of European liberty and security' (2009) Centre for European Policy Studies, Challenge Research Paper 16, 3.

57 Human Rights Watch, 'World Report 2014 (Events 2013)' 431-6 accessed 14 February 2017 at http://www.hrw.org/sites/default/files/wr2014_web_0.pdf; Amnesty International, 'Greece: frontier of hope and fear. Migrants and refugees pushed-back at Europe's border' accessed 14 February 2017 at http://www.amnesty.eu/content/assets/Doc2014/Greece_EUR 250042014.pdf.

58 Stijn Smismans 'How to be fundamental with soft procedures? The open method of coordination and fundamental social rights' in Gráinne de Búrca and Bruno de Witte (eds), The Protection of Social Rights in Europe: Changes and Challenges (Oxford: Oxford University Press 2005). 
has shaken the socio-economic basis of the European integration project; which leads us to the third and most profound reason why the fundamental rights myth may not survive.

With the financial and economic crisis the EU has entered an existential crisis. The fundamental rights myth might have little to offer to counter the EU's legitimacy crisis, both because it is interlinked with other European myths which have been strongly undermined by the economic crisis, and because the economic downturn, for which the EU is partially (perceived as) responsible, puts the defence of fundamental rights at risk.

The EU's fundamental rights myth is dependent on the economic myths ${ }^{59}$ that speak most directly to the foundational core of the EU as a market building project. The key political myth of the EU is that economic cooperation in Europe would lead to more welfare and ensure peace. Moreover, this process of 'ever more integration' would be irreversible. The economic and Eurozone crises that started in 2008 have profoundly undermined this myth. Although the origin of the crisis should not be attributed to the EU but to private banking practices and a lack of regulation, the shortcomings of the Eurozone construction are likely to have contributed to the economic practices at the origin of the crisis, while the lack of a timely institutional response has aggravated the situation. Moreover, when the EU finally did react, its solution was one of austerity policy. It is beyond the scope of this chapter to discuss whether countries would have been better off if they had either never entered the euro or had exited, or whether austerity would not have been the rule without the euro. ${ }^{60}$ However, it is certainly the case that the crisis and the austerity policies in response to it have created a lot of socio-economic hardship. The EU is partially responsible, and for some it is even perceived as the main culprit. The EU's key economic myth that European integration brings only more welfare for all appears to be strongly contradicted by the facts. Even the ancestral myth that European integration ensures peace is at stake as nationalism re-emerges and national narratives develop which either accuse other countries of imperialism or fall back into national stereotyping. As a result, both the credo of an 'ever closer union' and the idea of 'irreversibility' are under profound attack, with many considering the creation of the Euro was one step too far.

As the key economic myth of European integration is so profoundly shaken, it is difficult to see how the myth of fundamental rights can compensate for the decreased legitimacy of the EU, in particular because the economic crisis, and the austerity policies that followed, have contributed to a weakening of respect for fundamental rights. As the EU is partially responsible for the austerity approach, it can also be seen as contributing to this weakening of fundamental rights; or at least, it has not been particularly effective in reacting to increased fundamental rights breaches in its member states.

In terms of civil and political rights, the crisis has led to a widespread re-emergence of populism and nationalism, which has not only led to intolerance, but also to national

59 Erik Jones (n 12).

60 A non-euro country like the UK, for instance, has addressed the economic crisis with austerity, cutting welfare and restricting wages, while such measures have been minimal in, for instance, Belgium, despite its being part of the eurozone. 
governments taking measures that undermine civil and political rights. Countries such as France, Greece, the Czech Republic and Italy have been criticised for their treatment of Roma, ${ }^{61}$ while basic foundations of democracy have been undermined in, amongst others, Poland and Hungary (particularly freedom of speech), Romania (with respect to several pillars of the rule of law such as the independence of the constitutional court), ${ }^{62}$ and Spain (as protest movements against crisis management led the government to adopt measures restricting freedom of association). ${ }^{63}$ While the EU cannot be blamed directly for this behaviour by its member states, it clearly has not been able to ensure they respect fundamental rights. As argued above, the EU's tool kit in this regard is insufficient. Article 7 TEU requires unanimity and was not applied in any of the above cases. Although the European Commission managed in indirect ways to put some pressure on the member states, ${ }^{64}$ in most cases they have not adjusted their behaviour. At the same time, the EU's own democratic credentials have also been undermined by the crisis as the 'state of emergency' economic measures have been turned into a permanent new economic governance arrangement in which national parliamentary decision-making power over national budgets is to a great extent replaced by European technocratic governance. ${ }^{65}$

In terms of fundamental social rights, the picture is certainly no better. Austerity policies have widely affected fundamental social rights, such as the right to housing, income, education and health. ${ }^{66}$ These austerity measures have taken place within the budgetary requirements imposed by the EU, in particular for countries under bailout requirements. While the EU has contributed to such austerity measures, it has not provided a framework guaranteeing the respect of fundamental social rights in this context. This is illustrated by the case law of the Court of Justice which, upon several requests for preliminary references (mainly from bailout countries) to judge on fundamental rights breaches of national austerity measures, has argued it had no jurisdiction on the matter because the EU had not taken (social) legislative action on

61 Amnesty International (2014) 'Europe: 'We ask for justice': Europe's failure to protect Roma from racist violence', Report, 8 April 2014, accessed 14 February 2017 at http:// www.amnesty.org/en/library/asset/EUR01/007/2014/en/7c3cc69e-e84d-43de-a6a9-3732b4702df f/eur010072014en.pdf.

62 Gerda Falkner, 'The JCMS Annual Review Lecture. Is the European Union Losing its Credibility?' 2013 (51) Annual Review, Journal of Common Market Studies, 13, 20.

63 Amnesty International (2014) 'Spain: The rights to protest under threat', Report, 24 April 2014, accessed 14 February 2017 at http://www.amnesty.org/en/library/asset/EUR41/001/2014/ en/019b583d-9f93-484f-b7e0-e499126e2ebc/eur410012014en.pdf.

64 Falkner (n 62) 21.

65 Roland Erne, 'European industrial relations after the crisis. A postscript', in Stijn Smismans, The European Union and Industrial Relations (Manchester University Press 2012); and Christian Joerges, 'Law and politics in Europe's crisis: On the history of the impact of an unfortunate configuration', Constellations 21 (2014).

66 European Union Agency for Fundamental Rights (2013) Focus 'The European Union as a community of values: Safeguarding fundamental rights in times of crisis'; and Claire Kilpatrick and Bruno de Witte, 'Social rights in times of crisis in the Eurozone: The role of fundamental rights' challenges', EUI Working Papers LAW 2014/05. 
the issue. ${ }^{67}$ Hence, while the EU's new economic governance architecture (partially set out intergovernmentally and beyond the usual reach of the Court) imposes austerity, the social acquis of the EU and its weak definition of fundamental social rights does not provide a counterbalance. 68

Hence, in light of the economic crisis, both the EU's economic and fundamental rights myths risk turning into fairy tales only the most innocent would believe. In fact, increasing myth competition between the EU and its member states has set in. The EU can no longer easily 'mythologically free ride' on generic human rights references supposedly shared at national level and with the Council of Europe, as a return to discourses of national sovereignty on both economic governance and fundamental rights has set in, at least in some quarters. The UK provides the prime example of this, with the Cameron government asking for the phrase 'ever closer Union' to be deleted from the Treaty and core elements of the acquis communautaire to be renationalised, while national debate contesting supranational control over fundamental rights has surged since the country was condemned by the European Court of Human Rights for prisoners having no voting rights.

If the EU is to survive, and avoid turning into 'an ever looser Union' and a disintegrated market, it needs, more than ever before, inspiring narratives about its raison d'être, political myths that both inspire action and are widely appropriated. Fundamental rights can play a central role in this, but only if they de facto receive a more central place in the EU's institutional design.

First, as Gerda Falkner argues, when national politics are ever more prone to instability, parliamentary majorities are ruthlessly exploited for anti-democratic means, populism abounds, the media no longer perform their classic control function and the economy is in trouble, supranational safeguarding of fundamental rights and the rule of law is not a luxury. ${ }^{69}$ Therefore, the EU has a more prominent role to play in ensuring the rule of law and democracy within its member states. The European Commission has acknowledged this and, on 11 March 2014, proposed a new framework to safeguard the rule of law in the EU, based on a so-called 'pre-Article 7 procedure'. Under this new framework, in the first instance the Commission will assess indications of a systematic breach and start negotiations with the country by sending a 'rule of law opinion'. Unless the country makes the necessary adjustments, the Commission will issue a formal and public recommendation, on the basis of which the member state will be monitored. If there is no satisfactory follow-up to the recommendation, the Article 7

67 European Union Agency for Fundamental Rights (2013) Focus 'The European Union as a community of values: Safeguarding fundamental rights in times of crisis' 15 .

68 On a rare occasion, the Court has found its way via alternative ways. In its Aziz judgment, it empowered Spanish courts to stop repossession claims if based on unfair terms in mortgage contracts, and thereby allowed a better protection of the right to housing although that right did not appear in the European Court's reasoning. Maribel Gonza'lez Pascual, 'Welfare rights and euro crisis. The Spanish case', in Claire Kilpatrick and Bruno de Witte (eds), 'Social rights in times of crisis in the Eurozone: The role of fundamental rights' challenges', EUI Working Papers LAW 2014/05, 95.

69 Falkner (n 62) 27. 
procedure will be initiated..$^{70}$ This pre-Article 7 procedure provides a more persuasive approach, in contrast to Article 7 which has been considered, for example by Commission President Barroso, as draconian. Indeed, sanctioning via Article 7 requires careful consideration as it may further increase nationalist and populist reactions within the sanctioned country. However, general non-application of Article 7 may also be seen as a sign of weakness of the EU. The new framework for safeguarding the rule of law may therefore not be sufficient. Without the likelihood that Article 7 would be used, the pre-Article 7 procedure may lead to little.

To make both Article 7 sanctioning and pre-article 7 persuasion more successful it would be advisable to turn the unanimity requirement of Article 7 TEU into a requirement of a simple majority in both the Council and the European Parliament. One can also imagine other ex ante mechanisms. Falkner, for instance, suggests the creation of an 'EU Council for Democracy and Rule of Law', which could be composed of representatives from the EU Institutions, national constitutional courts, the CJEU and independent experts, and which would have the power to screen national constitutional reforms concerning pillars of democratic life such as electoral or media laws. ${ }^{71}$

However, it should be noted that, whatever new instrument is developed to increase the role of the EU in safeguarding democracy and the rule of law at the national level, the EU can only be credible if its own governance arrangements are more democratic. An analysis of this major challenge goes beyond the scope of this chapter, but at least an increased role for national parliaments in the EU's new economic governance arrangements is called for in this regard.

Second, it would be wrong to believe that, even when the EU comes out of 'the state of emergency' and the economy improves, it could return 'back to normal' and to the usual mode of permissive consensus. As the self-evidence of its economic added value has been undermined and socio-economic hardship has been keenly felt, stronger arguments to justify the further strengthened economic rule from Brussels will be needed. Indeed, the EU needs a narrative and approach in which not only economic but also social rights count as fundamental. This does not need to imply the creation of a European welfare state, but more the creation of instruments in which fundamental social rights can be strengthened at both national and EU level.

In relation to the national level, the $\mathrm{EU}$ could initiate an $\mathrm{OMC}$ on fundamental rights (including social rights). The rights provided by the Charter could be used as benchmarks to provide systematic planning by and assessment of the member states. Such a cyclical process could provide more detailed targets on the rights provided by the Charter, while the Commission and Council could assess member state action and provide recommendations. In contrast to the European Agency for Fundamental Rights, which has no mandate to monitor the member states systematically, such an OMC would not only provide systematic data from the member states but it would also provide wider political commitment, particularly via the Council, despite the nonbinding nature of an $\mathrm{OMC}$ procedure.

70 Press Release, 'The European Commission presents a framework for the safeguarding of the rule of law', accessed 14 February 2017 at http://europa.eu/rapid/press-release_IP-14-237_ en.htm.

71 Falkner (n 62) 27. 


\section{Research handbook on EU law and human rights}

In relation to EU level action, the EU's approach to the mainstreaming of fundamental rights could be strengthened. The European Commission's system of impact assessments (IAs) for all legislative and main policy initiatives provides an opportunity for the systematic screening of new policy measures in terms of fundamental rights. In 2011, the Commission adopted guidelines on how to take account of fundamental rights during such impact assessments. ${ }^{72}$ This has a different function to the legality check provided by the Commission's legal service. Such a legality check (which includes fundamental rights) is undertaken on the final Commission proposal. Instead, an IA should look at the potential fundamental rights consequences of the different policy options analysed in an IA. Unfortunately, the 2011 Guidelines are drafted mainly in a negative way, that is, an IA assessment is expected to highlight when a policy option may negatively impact on fundamental rights. Instead, IAs could be used more positively, as a way to actively and systematically promote the realisation of fundamental rights. IAs have to identify both the objectives of new policy interventions as well as the options for realising them. IAs could be used to systematically screen whether policy initiatives could (also) have the strengthening of fundamental rights as an objective and, subsequently, they could assess the public intervention options available with respect to this objective. Such an approach relies on an understanding of fundamental rights that is not limited to protecting individuals from abusive public intervention but instead relies on pro-active public intervention to promote fundamental rights (including social ones).

These are just a set of some instruments to improve the EU's fundamental rights credentials and none of these solutions constitute a miracle. Yet, a miracle is not what we need. A myth might do. Like miracles, myths are a question of belief, but unlike miracles, myths can survive despite their irony and contradictions, as long as they are substantive enough to inspire people to act upon them.

72 Commission Staff Working Paper 'Operational guidance on taking account of fundamental rights in Commission impact assessments' SEC (2011) 567 final. 